\title{
En form av television Globaliseringen av nationell TV-kultur
}

\author{
Af Göran Bolin
}

Det populare svenske spil- og underholdningsprogram, Bingolotto, har varet vist på national svensk tv lige så lange der har varet kommerciel tv $i$ Sverige. Programmet har haft skiftende succe siden starten i 1991 og havde på sit højdepunkt over 2 milllioner seere. Artiklen beskriver Bingolotto som et sarligt format inden for spil- og legeprogrammer. Det sker gennem en diskussion af formatbegrebet i forhold til begrebet genre, og gennem en identifikation af 4 karakteristiske dimensioner i formatbegrebet. Forfatteren fremhaver tv-formatet som en konceptuel beholder, der dels kan kapitaliseres, men som også kun kan anvendes på visse genrer. Desuden betragtes tv-formaternes fremvakst som et slags kulturelt oversattelsesarbejde i en globaliseret tid, hvor internationale formater versioneres til et bestemt publikum ved at give formatet nationalt kulturelt serpreg.

Televisionen har, oavsett om det rört sig om produktion och sändning av public service eller kommersiell typ, främst organiserats inom nationalstatens ram. Visst finns det undantag i form av lokal-TV, eller, som i USA, i regionala eller lokala utsändningar. Men huvudsakligen har sändningarna rört sig inom ramen för ett och samma språkområde. Detta gäller förvisso även radio, men ser vi till pressen, så finner vi en mycket starkare lokal förankring. Trots detta har t.ex. utbudet i de nordiska länderna haft stora inslag av program producerade i England eller USA. Utan tvivel har dessa program, deras innehåll och deras formspråk, haft inverkan även på den inhemska produktionen. Detta faktum tycks också ligga bakom den vilja de idag konkurrensutsatta televisionsföretagen i Norden visar att värna den nationella särprägeln, genom att anbefalla en viss andel inhemskt producerade program i utbudet.

Frågan rör i sin förlängning diskussionen om kulturell globalisering. Är det så att inhemska adaptioner av utländska förlagor ska ses som ett led i globaliseringen eller ska det ses som ett led i värnandet av det nationella? En faktor som måste anses som central för besvarandet av detta spörs- mål är frågan om format. Ett sätt att öka den nationella produktionen utan att behöva utveckla nya egna programidéer är nämligen genom adaption av utländska programkoncept. Mitt syfte i denna artikel är därför att diskutera fenomenet format i relation till de senaste decenniernas TV-produktion. Hur inverkar format på textuella uttryck i nationella TV-utbud? Vilka är de olika betydelser som kan tillskrivas formatbegreppet? Hur förhåller sig begreppet format till genre? Vilken är relationen mellan nationell och internationell TV-produktion, och vilka fenomen verkar internationaliserande respektive nationaliserande?

Det exempel jag kommer använda som utgångspunkt för min diskussion kring dessa frågor är det svenska spel- och underhållningsprogrammet Bingolotto, sänt på nationell TV i Sverige sedan 1991 (och lokalt i Göteborg sedan 1989). Analysen av Bingolotto som program och fenomen finns mer utförligt beskriven i Bolin \& Forsman (2002), men ska här utvecklas vad det gäller formataspekten. För att ge en vidare nordisk läsekrets en ungefärlig uppfattning av vad för typ av TV-program det rör sig om är det dock nödvändigt med en inledande kortare beskrivning av fenomenet. Därefter disku- 
teras kort formatbegreppet i relation till genrebegreppet, följt av en preciserad diskussion om vad ett format i olika medier innebär. I en fördjupad analys av Bingolotto söker jag sedan fånga detta specifika format, för att därpå avsluta diskussionen med några mer generella slutsatser om formatens karaktär och funktion.

\section{Bingolottos historik}

Bingolotto nådde under mitten av 1990-talet en enorm popularitet i Sverige, med ungefär två miljoner tittare varje lördag mellan 19 och 21 under sin storhetstid. Tittarna deltog i de tre bingospelen, tittade på de framträdande artisterna och lyssnade på de inringande telefonörerna när de vann konsumtionsvaror och pengar på de olika hjulen och lottsnurrorna. Publiken blev dock med tiden besvärande gammal sett ur det kommersiella perspektiv som värderar ungdomspubliker högt. Och detta perspektiv kunde knappast det sändande bolaget TV4 ignorera. Inte heller inom det Göteborgsbaserade produktionsbolaget var man särskilt förtjust i denna publik, men de var trogna tittare som köpte de bingolotter man spelade på $\mathrm{i}$ programmet varje lördag, 38-40 veckor om året. Tittarna bidrog därmed kraftigt till att finansiera den svenska idrottsrörelsen, vilka genom sitt samarbetsorgan Föreningslivets samarbetsorgan i lotterifrågor (FSL) var de som arrangerade lotteriet, och därmed stod som beställare av programmet. Det var också det lokala föreningslivet runt om i Sverige som stod för distribution och försäljning av de bingolottobrickor som man som tittare spelade på. En tredjedel av lotternas försäljningsvärde gick sedan tillbaka direkt till det lokala föreningslivet, vilket under åren som gått genererat ungefär en miljard svenska kronor årligen till föreningslivets verksamheter, framför allt idrottsföreningar och deras ungdomsverksamheter.

Det lokalbaserade produktionsbolaget Gert Eklund Television (GETV) grundades av medieintresserade personer inom den svenska idrottsrörelsen, något som också satte sin prägel på de tidiga årens sändningar, och skapade ett lokalt, personligt, och möjligen lite amatörmässigt textuellt tilltal. Detta kom så småningom att professionaliseras, och produktionen kom i sitt uttryck att bli mer och mer lik övrig underhållningsestetik, där det stundtals kunde vara svårt att skilja färgskalor och studioarrangemang från andra spelprogram, som till exempel Vem vill bli miljonär?, vilket sänds i samma kanal. Även organisatoriskt blev produktionen mer komplicerad, och snart skapades ett paraplybolag över GETV, det internationella Hollandsregistrerade spelföretaget International Gaming Systems (IGS).

Om den äldre publikens tillströmning endast delvis sågs med gillande av TV4 (de gav trots allt viss politisk legitimitet åt programmet; jfr. Bolin 2004), och inte efterfrågades av vare sig annonsörer eller sponsorer (jfr. Bolin 2002), så var de varmt omhuldade av programmets förste värd, Leif Loket Olsson. Olsson hade en bakgrund som handbollsdomare och lokalradiopratare, och hade en tydlig lokal och folklig förankring. När publiksiffrorna efter storhetstiden började dala byttes han dock ut mot den yngre artisten och underhållaren Lasse Kronér, även han med gedigen göteborgsk bakgrund. Inte heller han förmådde dock att få upp tittarsiffrorna, och efter ett par år överläts värdskapet till den svenske riksdalmasen och skidkungen Gunde Svan. Inte heller detta har kunnat få upp tittarsiffrorna, och programmet står nu inför sin svanesång, med ännu ett programledarbyte under hösten 2005.

Vad som gör Bingolotto unikt jämfört med andra svenska underhållningsprogram är att programmets historia sammanfaller med den svenska kommersiella televisionens historia, vilken i sin tur inte avviker stort ifrån övriga nordiska länder (jfr. Dahl \& Høyer 2003; Skovmand 1992; Bakøy \& Syvertsen 2001). Mitt huvudexempel utgörs således av en påtagligt nationellt förankrad produktion, ursprungligen också en tydligt lokalt förankrad sådan. Jag kommer dock att försöka diskutera formatproblematiken i ett vidare perspektiv, och dra ut analytiska trådar även till andra program och andra format, inom andra genrer och med annorlunda produktionsomständigheter.

\section{Genre}

Formatbegreppet används idag både inom akademin och inom medie- och TV-produktion (och distribution), likväl som i allmän kulturdebatt. Det är dock inte självklart att det är samma sak som avses i alla sammanhang. Formatbegreppet ska också relateras till det närliggande genrebegreppet.

En genre kan ses som ett slags formel (Cawelti 1976), eller som en kod (Berger 1992), som rör organiserandet av föreställningar och praktiker 
vad det gäller produktion, distribution och konsumtion av texter. Vanligtvis står det sistnämnda, det vill säga textnivån, i centrum, och ofta används genrebegreppet för taxonomiska klassifikationer och typologiseringar av det särskiljande och artgemensamma (ikonografi, berättarstrukturer, miljöer, roller, etc.). I enlighet med ett dylikt synsätt på genrer riktas intresset mot det som förenar och är (proto)typiskt i en klass av texter, där vanligt förekommande, återkommande och dominerande formelement, teman och stilgrepp kartläggs. Franskans genre betyder just bland annat typ, eller sort (Haettner Aurelius \& Götselius 1997). Dylika kartläggningar av "det typiska" i genren kombineras gärna med perspektiv på genrens historiska utveckling och popularitetskurva. Spel- och lekprogram, till vilken genre Bingolotto kan sägas höra, är något som alltid hört till det svenska TV-utbudet. Under monopoleran låg betoningen inom public service på frågesporter och game-shows, om än i några fall med möjligheter att vinna stora penningsummor (jfr. Sjögren 1997 s. 109ff). I takt med omregleringen och kommersialiseringen av TVmarknaden har antalet och varianterna av speloch lekprogram ökat avsevärt. Bingolotto växte, som redan nämnts, fram parallellt med att TV4 byggdes ut, och fann sin form samtidigt som det blev en del av TV4s kanalprofil.

Genrebegreppet är inte bara deskriptivt, utan även preskriptivt eller föreskrivande för hur texten ska utformas och tolkas. Genreföreställningar är således styrande för producenter och medför vissa tilltalsformer i förhållande till den tänkta publiken. Men genrebestämningar och avgränsningar utvecklas och förändras hela tiden i en institutionell och social praktik (produktion, distribution och reception). I linje med ett sådant mer processuellt synsätt uppfattas genrer som varandes i ständig rörelse och förändring. Man kan därför beskriva genrer som tidsbestämda tankemönster, eller som ett slags "kontrakt", som producenter och publik utgår från eller forkastar i en ständigt pågående "förhandling" (jfr. Neale 1980 och 1990). Det innebär att produktionssättet eller textens konventionsbundenhet inte är helt styrande eller ideologiskt determinerande, vare sig i produktionsledet eller för publiken.

Inom genreteori brukar man skilja mellan teoretiska och historiska genrer (Todorov 1975). En teoretiskt konstruerad genre är en klassifikation där en viss mängd texter med likartade uttryck el- ler innehållsdrag ges en viss benämning antingen i efterhand, till exempel av kritiker eller forskare (t.ex. Film noir), eller som ett stipulerat ideal att följa (t.ex. Aristoteles åtskillnad mellan tragedi och komedi). Historiska genrer syftar på textmängder som redan i sin "livscykel" är menade att vara och uppfattas som likartade. Det historiska genrebegreppet ligger närmare producenters, distributörers och publikers praktiker och klassifikationssystem. Bingolotto finner man någonstans i gränslandet mellan dessa. Det ingår i en tradition av spel- och lekprogram i TV och kan likaså förbindas med uppfattningar om och exempel på olika former av lördagsunderhållning för en familjepublik (t.ex. har många jämfört Bingolotto med den svenska klassiska lördagsunderhållningen Hylands Hörna).

\section{Format och medieform}

Då Bingolotto har sänts under så lång tid och i så många avsnitt, kan programmet närmast ses som en egen genre med sina egna speciella uttryck, förutsättningar och förväntningar. Alternativt skulle man kunna säga att Bingolotto har inneburit en radikal utveckling av spelprogramsgenren (i svensk tappning), i linje med t.ex. Steve Neales (1980, 1990) processuella tänkande kring genrer. Hur man väljer att se på detta skiftar måhända, men i stället för att reflektera över den generiska hemvisten kan man diskutera Bingolotto i termer av ett specifikt format. Formatbegreppet har använts på lite olika sätt i olika sammanhang. Dels skiftar betydelsen av formatbegreppet beroende på vilket medium man diskuterar, dels finns det olika användningar även bland dem som diskuterar samma medium. Gemensamt för alla dessa sätt att använda formatbegreppet är att det kan brytas ner $\mathrm{i}$ åtminstone fyra huvudsakliga dimensioner:

- som en teknisk term

- som programbestämning (programformat)

- som ett sätt att organisera tablåer och publik (kanalformat)

- som ett begrepp för en handelsvara

För det första är format således en teknisk term. Ursprungligen kan begreppet kopplas till den tryckta litteraturen, och anger där helt enkelt storleken på sidorna i en bok (Moran 1998 s. 13). Inom den rörliga bildens område avses på motsvarande sätt 
olika produktions-, lagrings och visningsformat. Inom filmindustrin skiljer man t.ex. mellan formaten 8,16 eller $35 \mathrm{~mm}$, och vad det gäller video och digitala distributionsformer kan man skilja mellan Betavideo, Digibeta, Video-8, VHS, DVD. Formatbegreppet återfinns även inom pressen, där man t.ex. skiljer mellan fullformat (broadsheet), Berliner och tabloid. Till skillnad från inom filmen, där formatskillnader indikerar amatörism eller professionalism (8 mm som amatörformat, 35 mm som professionellt format; jfr. Zimmermann 1995 s. 21ff), finns inget amatörformat inom presssen (om man inte vill betrakta fanziners A4-format som ett sådant). Vad det gäller format som teknisk term är det uppenbart att dessa är mediespecifika och att en formatdiskussion inom ett medium inte med automatik kan överföras på ett annat. I ett sammanhang där televisionen står i fokus kan vi dock bortse från press, film och video. Och även om man idag kan prata om olika format vad det gäller TV-rutans storlek, så är detta knappast avgörande för förståelsen av TV som medium.

För det andra, och mer viktigt för en diskussion om format i televisionen (och radion), används format i betydelsen programbestämning, som en term för att styra produktion av olika typer av TV- och radioprogram. Härvidlag kan ett programformat ses som en "underavdelning" till genre. Som exempel rymmer genren eller kategorin "talk shows" flera format: kommenterande magasin (current affairs), infotainment, etc. Det finns gemensamheter mellan dessa (en programledare, en studio, samtal, etc.), men också stora skillnader i hur de är strukturerade och gestaltade: samtalsämnena skiljer sig åt, programvärdarna agerar olika, infotainment-program har ofta artister på besök, en studiopublik, osv.

För det tredje kan man, särskilt i relation till radiomediet prata om kanalformat (formatradio). I denna betydelse står format för ett speciellt slags kanalprofil som ska fungera identifikatoriskt i relation till de lyssnare som kommersiella radiostationer vill sälja till sina annonsörer (Berland 1993). Här bidrar användandet av specifika musikgenrer, programledarens tilltal, jinglar och andra markörer till att radiokanalen lätt ska kunna identifieras av lyssnarna genom att bryta av mot det omgivande utbudet. Här har till exempel de svenska kommersiella radiostationerna utvecklat tilltal som ska skilja sig från public service-radion, vilket paradoxalt nog gjort att Sveriges Radios kanaler
P1, P2, P3 och P4 också identifieras väldigt lätt i utbudet, men då snarast $\mathrm{i}$ kraft av sin variation av programformer. Genom att radiokanalerna i de nordiska länderna (och delvis även i länderna $\mathrm{i}$ Baltikum) har gemensamma ägare, blir det också lätt att känna igen de övriga nordiska motsvarigheterna inom varje kanalformat.

TV-mediet har inte utvecklat lika förfinade formatformer i denna betydelse, möjligen beroende på att TV har tillgång till fler uttrycksmöjligheter vad det gäller att kunna laborera med både ljud och bild. Här fungerar logotyper i TV-rutans övre högra hörn som automatiska kanalmarkörer, vilket skapar större frihet att variera tilltalet i programutbudet inom varje enskild kanal. MTV, CNN, Discovery och andra konceptkanaler kan dock sägas utgöra formatkanaler i samma betydelse som formatradiokanalerna. Men även övriga TV-kanaler laborerar med vinjetter och tilltalsformer och även inriktningar i programutbud som ska hjälpa till att skapa specifika kanalprofiler. Utifrån en grundstomme utvecklas och omdanas dessa och andra komponenter i en ständig strävan att nå en avsedd publik och att kunna förutsäga och planera publikströmmar. Formattänkandet förenklar således $t a-$ blåläggning och särskiljer programmet i utbudet och i förhållande till dess genre. Ett programformat är dock aldrig fast, utan kan (och brukar) förändras över tid. Dels därför att förändring och "det nya" (nya inslag, ny scenografi eller grafik, etc.) i sig är ett attraktionsvärde. Dels därför att kanalernas extratextuella premisser kan förändras från säsong till säsong, t.ex. genom ledningsdirektiv om att nå nya målgrupper.

För det fjärde går det inte idag att bortse från att format inte bara är ett sätt att locka publiker genom specifika kanal- eller programprofiler, utan att format också är ett begrepp för en vara inom den internationella handeln med rättigheterna till olika programkoncept, både inom den kommersiella och den licensfinansierade sfären. Denna del av TV-industrin bygger på att det bakom ett visst programformat (Expedition: Robinson är ett exempel, Big Brother ett annat) finns några fasta premisser och formler (som anges i en s.k. "Bibel"). I övrigt går dock formatet att förändra och anpassa allt efter de förutsättningar och föreställningar som är aktuella i det land, den region eller den TV-kanal till vilken det säljs. Enligt Bingolottos skapare Gert Eklund, som i sin tur lånade idén med TV-sänd bingo från dansk lokal-TV, är bingospelen den 
grundbult som håller ihop programmet och programserien - allt annat kan förändras. Även om bingospelen är en central ingrediens i programmet, är det dock tydligt att formatet även bygger på andra delar: ett folkligt tilltal, attraktiva vinster och höga prissummor på uppåt flera miljoner, en programledare med folklig och helst också idrottslig framtoning, etc. En annan viktig komponent i formatvaran är den möjlighet till konsultservice som åtföljer ett licensieringsavtal. När Bingolotto skulle lanseras i Ghana reste en person från det svenska produktionsbolaget ner för att vara behjälplig vid inledningen av produktionen.

I denna sista betydelse är format ett slags motsvarighet till copyright, dvs. ett eknomiskt-juridiskt begrepp som handlar om vem som äger idén eller konceptet, och har rätt att sälja den. En copyright gäller bokstavligen rätten att kopiera ett verk, t.ex. att få kopiera och vidaresälja en videokopia av ett enskilt Bingolotto-program. Att äga ett format, däremot, gäller rätten att kunna kapitalisera själva programidén på vilken sedan en räcka av liknande program kan produceras och adderas i en serie för den TV-distributör som sänder det. På så sätt kan TV-produktionen rationaliseras enligt en ekonomisk logik, så att vissa produktionsbolag är bra på vissa format (t.ex. TV-sända insamlings- och välgörenhetsgalor som den svenska Faddergalan som med jämna mellanrum sänds i arrangemang av TV4 till förmån till underprivilegierade barn världen över, eller den paneuropeiska Eurovision Song Contest), medan andra specialiserar sig på andra format. Mycket riktigt har det också visat sig svårt att $i$ juridiska tvister avgöra var gränsen går för vad som kan räknas som ett intrång i de intellektuella rättigheter som omgärdar ett format (Moran 1998 s. 15ff). Trots detta fungerar formaten inom TV-industrin som handelsvara eftersom de flesta anpassar sig till systemet med rättigheter och licensavtal. Man skulle kunna säga att systemet överlever på grund av den upparbetade tro på systemet självt som genereras inom TV-produktionens fält snarare än på den juridiska regleringen (jfr. Bolin 2004). I detta uppvisar formaten en likhet med publiken som vara, eftersom båda kategorierna bygger på en outtalad överenskommelse om att det är dessa kategorier som utgör den prisregleringsmekanism som reglerar varans ekonomiska bytesvärde (Bolin 2005). Ytterst är format som begrepp enligt australiske TV-forskaren Albert Moran endast begripligt i kraft av formatets performativa funktion:
The term has meaning not so much because of what it is but because of what it permits or facilitates. A format is an economic and cultural technology of exchange that has meaning not because of a principle but because of a function or effect.

(Moran 2004 s. 6)

Här är det tydligt att Moran inte avser format i betydelsen teknologisk form, utan mer ser till dess kommersiella och semiotiska potential. Hans diskussion kring formatens betydelse visar dock att det är möjligt att finna kopplingar mellan alla dessa användningar av begreppet format. De kan betraktas som perspektiv att anlägga på fenomenet, och det är fullt möjligt att utföra analyser av specifika fenomen i televisionen eller i andra medier genom att betona ett eller flera av dessa perspektiv samtidigt. Att en TV-kanal kan ses som ett format i sig - t.ex. ungdomskanalen Z-TV i Sverige - utesluter ju inte att de enskilda programinslagen kan vara adaptioner som det köpts rättigheterna till. Snarare kan man betrakta det som att den ökande betydelsen av tablåläggning, och den ökade betydelsen inom kommersiell television av att nå "rätt" publik till varje programslot i tablån, gör format i båda betydelserna mer aktuellt som begrepp. En högt standardiserad, eller, om man så vill, professionaliserad, produktionsapparat, inte bara möjliggör, utan även kräver en ökad grad av specialisering inom distributionen av program.

\section{Formatet Bingolotto}

Bingolotto kan således betraktas som ett format - konceptet går att köpa och anpassa till andra nationella kontexter och programmet har i sig ett speciellt tilltal och kännetecknande profil. Exportförsök har också skett vid flera tillfällen: till Norge, Finland, Tyskland, Estland, Ghana och flera andra länder. Ingenstans har det dock fått det enorma genomslag som det haft i Sverige (Bolin \& Forsman 2002). GE Television/IGS, som alltså utvecklat Bingolotto-formatet, har också lanserat andra format. Zesam var ett format som sändes under en period. Precis som Bingolotto var det ett spelprogram. Ett annat format som erbjudits på produktionsbolagets hemsida är Qlever, ett frågeprogram som dock inte tycks ha lockat någon köpare och följaktligen inte sänts vare sig i Sverige eller någon annanstans. På företagets hemsida beskrivs Qleverformatet på detta vis: 
A state of the art and flexible interactive Game Show

Qlever is based on the latest technology for TV formats. The show is a highly interactive, exciting and preferably daily live game show for any specific target group. It is a very flexible concept that can be adapted to any market requirements. By calling into the show, the viewers have the possibility of winning fantastic prices.

Since all the games are graphically displayed and connected to our sophisticated software, the viewers control the action on the screen by using their own telephones.

(www.igsnv.com/, accessed 010201)

Precis som Bingolotto och Zesam bygger Qlever-formatet på livesändning och där publiken med hjälp av en spelbricka ska försöka lösa en kod och därefter ringa in till programmet. Likt Bingolotto och Zesam finns här även en koppling till Internet, som erbjuder kompletterande tävlingar till dem som ingår i programmets TV-utsändning. Utöver detta producerar IGS tävlingsformat för Internet med namn som Cash Back och Star Game.

En mycket viktig del i både Bingolotto- och Qleverformatet är den mjukvara som spelformen bygger på. I Bingolottos fall handlar det om det datasystem som utvecklades och gjorde det möjligt att kringgå den svenska lagstiftning som förbjuder direktdragning av lotterier i TV. Dragningen görs därför strax innan programmets sändning, och spelet på bingobrickorna är egentligen ett sätt att rätta sin lott och se om ens lottnummer - unikt för vare enskild lott - har givit vinst. Därför är det heller inte konstigt att flera av företagets andra format inte är menade för televisionen utan för Internet.

Vari består då formatet Bingolotto, förutom av konstruktionen av lottdragningen? I linje med Abert Morans uttalande om formatens funktionalitet och möjlighet att attrahera specifika publiker kan ju knappast en enskild dataprogramvara räcka som definierande element. Vilka är de grundstenar konceptet är byggt på? Eftersom Bingolotto till skillnad från Qlever inte beskrivs på företagets hemsida (tanken är nog att exemplifieringen vid eventuell licensiering utgörs av själva programmet i sin sändningsform), måste vi röra oss närmare programtexten för att kunna svara på den frågan. Detta gör det påkallat att se vilka huvudsakliga beståndsdelar formatet är uppbyggt av, och hur dessa beståndsdelar uppkommit under programmets historia.
Likt programmets skapare Gert Eklund kan man utgå från själva bingospelen som en grundläggande beståndsdel. I den nationella varianten är programmet uppbyggt kring tre olika bingospel, vilka också avgränsar programmet i tre relativt lika långa delar mellan vilka det sänds reklam (de lokala sändningarna innehöll fem spel). Av hänsyn till den svenska lagstiftning som reglerade TV-reklam i Sverige under 1990-talet, var tablåläggningen konstruerad så att det egentligen rörde sig om tre olika program - Bingolotto 1, Bingolotto 2 och Bingolotto 3 - eftersom man vid den tiden inte kunde bryta enskilda program för reklam. Numera är det tillåtet att bryta program för reklam - en lagändring som kom till stånd bland annat som en följd av GETVs agerande och närmast konsekventa förmåga att balansera på gränsen till vad som var lagligt möjligt i fråga om reklam. Programmets struktur med tre delar fortsätter dock.

Även om bingospelen kan sägas utgöra den viktigaste beståndsdelen i formatet, bör man dock, trots Eklunds uttalande om motsatsen, addera några andra viktiga komponenter som ingår i formatet: livekvaliteten, det folkliga, inklusive tilltalet som med den förste programledarens ord bjuder in "alla att vara med", de interaktiva möjligheterna att ringa in till programmet och vinna vinster, populärmusik med bred förankring, en programledare med folklig framtoning. Alla dessa komponenter är dock tydligt underordnade det faktum att programmet ska redovisa bingospelen, och i detta ligger att programmet tydligt präglas av vad man skulle kunna kalla en "funktionsestetik", något som rimmar väl med Morans hävdande av formatens funktionalitet. För att beskriva denna estetik lite närmare ska jag ta upp två av dessa komponenter: livekvaliteten och programledarrollen.

För det första är det av avgörande betydelse för Bingolottos funktionsestetik att merparten av programmet spelas in och sänds live i realtid. Till skillnad från många andra livesända program har även musikinslagen varit live, även om undantag gjorts för internationella storstjärnor som David Bowie och Ricki Martin.

Det faktum att Bingolotto är ett spelprogram, med simulering av en direktdragning som sin mest karakteristiska beståndsdel, gör att just liveaspekten kan ses som den viktigaste grundkoden i Bingolottos produktion, text och reception. När alltfler studiobaserade underhållningsprogram spelas in "live on tape" (dvs. med vissa möjligheter till efter- 
redigeringar) framstår Bingolotto, genom att vara en så pass omfattande liveproduktion, som något särskilt i det svenska TV-underhållningsfältet.

\section{Liveness}

Man kan i linje med många TV-teoretiker säga att livekaraktären (liveness) är karakteristiskt för TV-mediet och tillika en av dess mest grundläggande koder (Feuer 1983; Heat \& Skirrow 1977). Det finns en rad narrativa konventioner för att skapa en känsla av att program är "direktsända", och livekvaliteten hör intimt ihop med TV-mediets grundläggande produktions-, narrations- och representationskoder, liksom med dess karakteristiska tilltalsformer (Fiske 1987). Även de program som faktiskt är liveproduktioner - som Bingolotto - måste vara "kodade". Live eller liveness är alltså en grundläggande TV-kod men det är också en genrebunden kod. Nyhetsprogrammen har sin livelogik, spelprogram sin (nyhetsprogram har till skillnad från de flesta spelprogram exempelvis inte någon studiopublik). Enligt Fiske (1987), Jantzen \& Møller (1993) och Skovmand (1992) betonas just liveaspekten i spel- och lekprogram även då dessa är förinspelade. Vi tittar på, och engagerar oss i, sådana förinspelade spelprogram som om skeendet vore simultant med vår upplevelse, dvs. som om händelserna utspelades samtidigt som vi tog del av dem. Programledarens direkta tilltal, flerkamerateknik, möjligheterna att delta i spelet, bilder av publiken i studion, betoningen av möjligheten att alla kan vinna tillhör det som på olika sätt skapar en känsla av närhet, direkthet och gemenskap.

Även om hela eller delar av programmet är förinspelat ter det sig ofta som direktsänt i kraft av att man använder flerkamerasystem som gör det möjligt att följa en rörelse eller händelse i realtid. Också då en redigering av ett förlopp eller framträdande gjorts, bygger berättandet i TV i hög grad på realismens logik och traditioner av att visa förlopp som verklighets- och vardagsnära, kausala och framåtskridande (Bourdon 2000). En sida av realismkoden var länge att man inte skulle se hur programmet konstruerades utan att det skulle framstå såsom transparent - som om det kom till tittaren utan ett tekniskt mellanled och en kulturell kodning. Detta var länge idealet också i Bingolotto, och det sågs av de programansvariga i produktionen som ett tecken på ett slags oprofessionalitet om bildkontrollen av misstag plötsligt lät tittaren se någon av kameramännen.

Två viktiga produktionstekniska aspekter då det gäller Bingolotto är att man använder sig av direktredigering (i bildkontrollen) och flerkamerasystem. Eftersom sammanfogningen (montaget) av bilderna sker direkt och genom att kamerorna - enligt vissa rörelsemönster och med sina respektive "bevakningsområden" - följer vad som sker i studion, skapas en överensstämmelse mellan den tid det tar för något att ske, och den tid det tar för detta att återges. Detta är inlemmat i det dominerande TVberättandet, som i grunden fortfarande bygger på att det bekanta och "familjära", likväl som det nya och främmande, representeras på ett sätt som ger en känsla av sammanhang och förklaring i en sammanflätning med våra egna invanda tankemönster och vardagliga livshorisonter: TV-realismen "liknar" vårt sätt att perceptuellt och kognitivt uppfatta och göra reda för världen (Wilson 1993). Bingolotto är en produktion skapad med en TV-studio som händelsecentrum. Man kan med Hall (1971/1996 s. 6) tala om att det finns två huvudsakliga produktionssätt för studiobaserade TV-produktioner: staged performance och studio production. Det förstnämnda avser främst program som återger ett i förväg givet manus, typ TV-teater (pjäser, sitcoms, såpor etc.), det andra program som Bingolotto, som har en TV-studio som utgångspunkt och där själva TV-situationen är det centrala.

Programledaren är också central för skapande av livekänsla, igenkänning och direkthet: programledaren vänder sig direkt till kameran och talar så att säga till oss, som om det skedde i en "dialog" och i samma stund som vi tar emot deras ord och blickar (t.ex. spelprogram och nyhetsprogram). Detta direkta tilltal skapar en känsla av dialog, delaktighet och utvaldhet i den kommunikativa situationen. Det direkta tilltalet bidrar i samspel med den realistiska berättar- och redigeringsstilen, flerkamerateknik och det (fotografiska) avtrycket till känslan av att dessa program utspelas samtidigt som vi ser dem.

\section{Live som Bingolottokod}

Många av dem som arbetar med Bingolotto betonar också vikten av att programmet ska spelas in och sändas live. Det finns givetvis förprogrammerade grafiska inslag och förinspelat material - t.ex. vinstpresentationsfilmerna, stämningsbilder under 
bingospelen, vissa artistframträdanden. Annars är merparten av programmet livesänt. Detta har i sig blivit en produktionskod för hur man jobbar med programmet. Att skapa livekänsla i ett TV-program handlar en hel del om planering av det oförutsedda. Under åren har utvecklingen av programmet gått mot en ökad professionalisering i produktionen och av uttrycket. Samtidigt har man värnat om eller sökt nya vägar att "koda" den känsla av oförutsägbarhet och improvisation som produktionspersonalen och kanske också tittarna förknippar med livesändningar, vilket bland annat inneburit att man lagt in små överraskningar för programledaren för att kunna fånga dennes spontana reaktioner på ett mindre inövat sätt.

Enligt Gert Eklund var det ett principbeslut att programmet skulle sändas live. Detta togs när man inför hösten 1989 bestämde sig för att satsa på bingolottoformatet, trots det nedslående resultatet för de tre provprogram som sändes lokalt under våren samma år. Att konstituera Bingolotto som en liveproduktion var också ett sätt att få den dåvarande radioprataren och "direktsändningsmänniskan” Leif Olsson att ställa upp som programledare:

Loket trodde inte på det, och så sa jag att om man gör detta som jag vill att det ska göras, i direktsändning med människor som ringer in till programmet så får det en helt annan nerv och då kommer vi att lyckas med detta.

(Gert Eklund 27.01 2000)

I och med att producenten Sverre Andersson liksom den övriga produktionspersonalen på det stadiet inte hade några nämnvärda tidigare erfarenheter av TV-produktion, kom de att tränas i detta produktionssätt. Att programmet sänds live är också något som alltsedan starten i TV4 framhållits redan i påannonsen: "Bingolotto - direkt från Göteborg".

Liveaspekten är grundläggande i förhållande till själva tanken bakom eller uppfinningen av programmet - att koppla samman dragningen i lotteriet med bingospelet. Eftersom dragningen egentligen är gjord på förhand gäller det att skapa en illusion eller en simulation av en livesituation, och här lämpar sig bingospelet väl. Eftersom tittaren, i enlighet med vissa genreförväntningar, godtar filmfiktionens många fantasisituationer och konstruerade spänningsmoment, är det fullt möjligt att leva sig in i bingospelet och uppleva det som direktsänt. Givetvis bygger denna känsla i hög grad på att tittarna/spelarna själva deltar i spelet genom att markera numren på sina brickor med programledaren som ciceron och uppläsare. Det skapar en illusion av att spelet avgörs samtidigt som man spelar det - eftersom man rättar sin lott i realtid när bingonumren läses upp. Någon tid för tvekan ges heller inte, eftersom alla garanterat har det nummer som ropas upp i någon av raderna på sin bricka. Sedan gäller det visserligen att ha rätt kombination av siffror för att bli en vinnare. Eller, rättare sagt, att ha rätt lottnummer på sin bingobricka.

Till Bingolottos format och livekod hör också de telefonsamtal som kommer "direkt" in i studion. Programledaren kan inte i förväg med säkerhet veta hur samtalen ska utvecklas, även om det finns en ganska strikt formel för hur de brukar vara uppbyggda, som både programledare och telefonör oftast är böjda att följa. Den osäkerhet och dråplighet som ibland kunnat prägla samtalen gjordes det tidigare en stor poäng av. Bland annat gavs det under Leif Olssons tid ut en video (Bingolottos bästa) med "roliga" samtal.

I vissa lotterimoment har programledaren till uppgift att ringa upp en vinnare. Eftersom denna dragning faktiskt sker direkt så kan inte vinnaren i fråga vara informerad innan, och är därför inte alltid hemma. Således händer det ibland att programledaren ringer upp utan att få något svar. Detta blir i sammanhanget ytterligare en markör för programmets livekaraktär.

Även om livesituationen bygger på att kamerorna enligt ett mer eller mindre konceptualiserat och inrepeterat mönster "återger" vad som händer i studion, så är bildkontrollen själva navet i sammanställningen av dessa, liksom i skapandet av programmets direktkaraktär. I bildkontrollen, där man också har att hantera alla förinspelade inslag $\mathrm{i}$ programmet, ges inte tid för längre överväganden enligt bildproducenten Peter Damerau:

[M] an får inte sitta här och vara "oj, vad händer nu?, oj!”, utan det ska ju sitta mer i ryggmärgen, så man ska inte tänka för mycket. Det brukar bli fel om man börjar tänka: "Vänta nu, var det här jag skulle...?"

(Peter Damerau 4.6. 1999)

Också den rumsliga aspekten av inspelningssituationen är av betydelse. Det förlopp som fångas och gestaltas sker (mestadels) i ett slutet rum (studion) med en studiopublik som efter direktiv applåderar samtal, dragningar och artister, vilket också det 
bidrar till livekänslan och den tidsmässigt sammanhållna karaktären.

\section{Programledaren i centrum}

I skapandet av livekänslan har givetvis programledaren en nyckelroll. Det är programledaren som skapar sammanhang och kontinuitet i programmet, både genom sitt sätt att tilltala publiken och genom sin närvaro. Programledaren skapar även kontinuitet mellan programmets olika delar. Redan i påannonserna betonas programledarens vikt av kanalens programpresentatör, och för många tittare är det också programledaren (såväl i underhållnings- som i nyhetsprogram) man förknippar med en viss programtitel. Programledaren kommer således ofta att uppfattas som en galjonsfigur och blir lätt en symbol för hela programmets "varumärke". Genom skriverier i pressen kan programledaren också komma att upplevas som något av en nära bekant, och när programformat förändras kan programledaren fungera som en kontinuitetsskapande faktor.

Programledarrollen är på flera sätt kopplad till en vidare medial och publik kontext, men är också en funktion i programmets narrativa universum, ty programledaren ska agera för att leda händelserna i studion och kommunicera med de tilltänkta tittarna. I sitt arbete i studion förklarar programledaren programmets premisser (vad går detta program ut på, vad ska hända ikväll). Programledaren ska också binda ihop inslagen (med på- och avannonser). Och i sin egenskap av programmets "värd" välkomnar denne tittarna och introducerar och småpratar med gäster, artister och andra som kommer på besök till studion. Programledaren besitter också en "privilegierad blick" genom att, som om i en dialog, kunna vända sig direkt till kameran/tittarna och därmed guida dem in i den sociala gemenskap och den känsla som programmet aspirerar på (jfr. Bruun 1999 s. 148 och 227). Med dessa bilder och kryssklippning - baserad på frågor, kommentarer och blickar - fungerar programledaren således som ett kitt i TV-programmets uttryck och diskurs.

Att leda underhållningsprogram handlar i hög grad om att skapa en känsla av (mer eller mindre) lättsam socialitet och samvaro. Till skillnad från nyhetsvärdar och andra i genrer där neutrala ansiktsuttryck och ett faktaorienterat och analytiskt ordval står i centrum kan programledare för underhållningsprogram använda sin kropp, sina gester och sin mimik som uttrycksmedel. (Denne visas också gärna i vida halvbilder och helbilder, stående och i rörelse på studiogolvet.) Förmågan att samtala och ställa frågor på ett lättsamt sätt till gäster i studion hör också till jobbet.

I alla dessa avseenden är programledarrollen mycket central i Bingolotto. Under lång tid var programmet också närmast synonymt med sin programledare Leif Loket Olsson, och det är svårt att finna motstycke till den vurm och också kult och kritik som under stor del av 1990-talet omgärdade denne person. Olsson blev "Loket" med hela svenska folket och syntes förutom i Bingolotto i många andra offentliga och "folkliga" sammanhang, som auktioner, travtävlingar och invigningar av olika slag. (Själv skilde han på sin TV-persona och sitt privata jag genom att tala om "Loket" i tredje person). I kraft av många dylika externa uppdrag och i linje med sina erfarenheter från direktsänd radio hade Olsson en osedvanlig förmåga att klara direktsändningssituationen och samtalet med telefonörer och andra tävlande/spelare. Genom att ha lett programmet redan i lokal-TV kom han att bli en viktig faktor i hela programmets uppbyggnad och också för hur det skapades. Olsson hade också egna och bestämda uppfattningar om vilken karaktär programmet skulle ha.

Förutom att agera bingoutropare är en annan dimension av programledarskapet i Bingolotto samtalen med telefonörer och gäster i studion. Detta var en del av arbetet som Leif Olsson ofta beskrevs vara en mästare i. Han ansågs exceptionell i sin förmåga att "ta folk" och lägga sig på deras nivå. Ofta kryddade han samtalen med små gemytliga skratt när han visade prov på sin förmåga att kunna identifiera i stort sett varje ort i Sverige geografiskt. Olssons agerande - och även scenografin och tilltalet i stort - framstod i hög grad som utåtriktat och inbjudande, som att tittarna bjöds hem till Olsson: "Välkomna. Tack för att ni kommit", säger Olsson till tittarna i presentationsfasen i ett tidigt avsnitt (911026) av programmet. Loket hade en mycket stor repertoar av verbala intimitetsstrategier för att skapa ett behagligt samtalsklimat: frekvent upprepande av telefonörens namn, kontakskapande uttryck som "hör du", "vet du", "ser du", komplimanger och beröm, skämt, skratt och andra gemenskapsmarkörer. Att personerna i publiken var viktiga inte bara som "ögonpar" i en tittarskara utan också som finansiärer av idrotts- 
rörelsen genom att köpa lotter var något som ofta underströks under Loket-eran, genom programledarens ständiga uppmaningar till lottköp.

\section{Planlagda missar}

Sett ur ett produktionsperspektiv är programtiden och ordningsföljden mellan olika inslag av stor vikt, ty under en livesändning kan oväntade saker ske, och luckor i programmets flöde kan uppstå. Detta var ett skäl till att man i Bingolotto länge hade dansband som spelade, eftersom dessa orkestrar har en omfattande repertoar och kan "dra en låt till" om så skulle krävas för att få programlängden att stämma med TV4s övergripande tids- och annonstablå. Likaså gjorde man redan tidigt en poäng av det som producenten talar om som "goofar", dvs. olika tekniska och mänskliga missar i programmet: programledaren tittar in i fel kamera, krångel med telefonsamtal, inslagen kommer i fel ordning, fel vinjetter eller grafik läggs plötsligt in, osv. Risken för fadäser och vikten av att artisterna skulle spela live vändes till att bli en del i beskrivningen av "programmets själ". Inte minst då Leif Olsson, med lång träning från direktsändningar i (sport)radio, talar om programmet:

Jag tycker att det är jätteviktigt. Det är ju ren bluff, att komma hit och sätta på en skiva! Det ska vara levande, det ska vara live, det ska kunna gå åt helsike, det ska kunna bli så att jag tappar rösten så att de måste spela en låt: Det kan de ju inte, om de inte kan spela.

(Leif Olsson 991010)

Under sin tid var Loket Olsson en väldigt viktig del i programmets livekaraktär. Något direkt manus förutom körschema med lite anteckningar använde han sig inte av, och han repeterade heller inte innan sändning. Under sändningen hände det ibland att Olsson "avvek" från det uppgjorda konceptet, eller bokstavligen valde att gå sina egna vägar på studiogolvet. Denna understundom något improviserade inspelningsstil, allt efter programledarens agerande, kallades internt för "Följa Leif".

Leif är väldigt spontan. Han tycker inte om att repa. [...] Han tror det är som radio: "Jag står här", och ...jaha, "nu går jag hit", och "nu står jag här" och "nu pratar jag med Birgitta här". Han tänker radio. Det är väl lite av charmen också.

(Peter Damerau 990604)
Givetvis var missar vanligast under de första säsongerna av Bingolotto. Med tiden förbättrades handlaget och professionaliteten ökade. Men kring Olssons agerande fanns som redan nämnts en viss oberäknelighet i rörelsemönster och agerande. Han drog sig heller inte för att bryta fasaden och gå vid sidan av kameran för snabb konsultation med producenten, och inte heller för direkta och ibland skarpa påpekanden till den tekniska personalen medan han låg ute i bild. Detta hade också konkret inverkan på programmets utseende. Eftersom Loket inte repade utan "sprang omkring”, och producenter och kameramän fick följa honom, var det nödvändigt att använda ett brett, allmänt ljus för att undvika alltför stora kontraster. Efterföljande programledare har haft ett fastare inrepeterat rörelsemönster, vilket gör att ljussättningen kan sättas mer exakt.

Att ha en beredskap för det oväntade hör till livesändningens premisser, men i och med bytet av programledare förändrades Bingolotto på många sätt. Till den omläggning som följde efter Lokets avsked hörde också att man - för att framhäva livekaraktären och få en komisk effekt och tätare samspel i personalgruppen - lade in "Studiomannen Janne". I ett antal program under sin första höst (1999) skojade producenten och hans medhjälpare också med Kronér genom att mixtra med de telefonlurar som han skulle använda då samtal kom till studion. Ett annat exempel på denna typ av mer planlagda misstag finner man i ett avsnitt från hösten 1999 när Lasse Kronér vid sin entré kommer in och snubblar till på studiogolvet - något som skedde flera gånger och som dessutom är etablerat som en autenticitetskod vid programledarens entré i vissa amerikanska talkshows. Likaså är hänvisningar till och snack med produktionspersonalen ofta använda grepp i amerikansk TV-underhållning. Exempelvis kan man se ett visst inflytande från Late Show med David Letterman (Z-TV), där Kronér, precis som Letterman, ofta småpratar med orkesterledaren för husbandet (vilken i båda fallen sitter vid sin keyboard). Ytterligare en förändring som skedde 1999 var att man till skillnad från tidigare inte drog sig för att visa kameramännen i bild. Att visa programmets produktionssida på detta uppenbara sätt blev redan under 1980-talet en del i en mer "postmodern" form av television, och en del i en stilistisk reaktion på den tidigare TV-realimens förmenta osynlighet genom att man betonade själva medialiseringen (jfr. Caldwell 1995). 


\section{Formatadaption som kulturell globalisering}

Som förhoppningsvis framgått av redovisningen ovan bygger Bingolotto-formatet på (åtminstone) tre saker: bingospel kopplade till ett specialdesignat dataprogram, livekvalitet samt en tydlig programledarroll. Som också torde ha framgått av det ovan beskrivna har dessa grundkomponenter också förändrats genom åren, och man har experimenterat med att byta ut enskilda moment i programmet (till exempel tog man under våren 2005 bort artistframträdandena). Att en viss typ av programledarpersonlighet är viktig är måhända inget som är unikt för Bingolotto. Detta delar programmet med andra inom underhållningsgenrerna. Snarare ska man se det som att det är den folkiga, icke-urbana framtoningen som är det kännetecknande för denna programledartyp. Men även om programledare kan komma och gå tycks det svårt att förändra grundkomponenterna bingospel/lotter och livekvaliteten i sändningen. Däri ligger essensen i Bingolottos format.

Utifrån detta kan det nu vara dags att mot bakgrund av ovanstående diskussion reflektera något över formatfenomenet inom televisionen. Det tycks då lätt att med Albert Moran utgå ifrån formatens funktionalitet kopplat till deras varukaraktär. Man skulle kunna säga att ett format, i betydelsen immateriell vara som säljs på en marknad, mer är att likna vid ett dataspel än en bok. Boken är unik i sitt (oftast) linjära narrativ. Ett dataspel däremot, erbjuder sin användare en möjlighet att ta del i en konceptuell värld, t.ex. genom att tävla med andra i biltävlingar, fotbollsmatcher, etc. Man kan säga att behovet av att lansera en typ av konceptuell copyright uppstår som en följd av den ökade graden av interaktivitet i relation till medierna. När varje enskild spelomgång vid ett dataspel skiljer sig en smula från föregående, kan man inte tala om rättten att kopiera, eftersom möjligheten att kopiera förutsätter ett original som man skapar en identisk avbild av. En idé, däremot, som t.ex. principerna för hur en biltävling, fotbollsmatch, etc., kan spelas, medger inte exakta kopior, utan en räcka variationer inom en strukturellt uppställd ram. Så fungerar också TV-formaten som konceptuella behållare som kan fyllas med semiotiska variationer baserade på nationellt och kulturellt specifika enskildheter.

Det synes viktigt att tydligt särskilja formatbegreppet från genrebegreppet. En genre kan inte kapitaliseras, eftersom genrens principer bygger på alltför allmänna konceptuella karakteristika (som ständigt förändras). Ett format, däremot, har en yttersta konceptuell kärna (ett antal bingospel, en digital mjukvara, ett hus med inlåsta människor i, en ö med strandsatta människor, ett antal konkurrerande friare, en återsamling av gamla klasskamrater, etc.).

Av den anledningen är format också enbart möjligt att knyta till vissa genrer, främst inom underhållning. Det är t.ex. svårt att betrakta fiktionsserier som format $\mathrm{i}$ betydelsen varor som kan adapteras nationellt, eftersom fiktion delar romaners karakteristika av att vara avslutade "verk" med en författare, regissör, etc. Inom fiktionen kan man göra en remake, något som den amerikanska filmindustrin tillämpat systematiskt. Inom radio och TV-industrin görs det förvisso ibland remakes av olika serier, men då brukar det snarast handla om att återuppliva rollfigurer och teman snarare än att återinspela gamla avsnitt. Ett sådant välkänt exempel är Star Trek och Star Trek: The Next Generation. Det är måhända motsvarigheten till underhållningsgenrernas formatadaption.

Både fenomenet med remakes och format kan sägas handla om ett kulturellt översättningsarbete. Man skulle kunna se formatens framväxt som en förlängning av denna översättningstrend inom filmens värld, och som ett sätt att nationalisera eller regionalisera en viss typ av innehåll som man misstänker är alltför kulturellt avvikande för en viss nationell eller regional publik. Och måhända är det detta fenomen som utgör navet i det som kallas kulturell globalisering: genom formatadaption och återinspelningar knyts världen samman av berättarformer som har den dialektiska kvaliteten av att ha både ett gemensamt ursprung och en nationell särprägel.

\section{Referenser}

Abercrombie, N. (1996). Television and Society. Cambridge: Polity Press.

Bakøy, E. \& Syvertsen, T. (Eds.) (2001). Sjekking på TV. Offentlig ydmykelse eller bare en lek. En studie av Reisesjekken - programformat, delttakere, produsenter, sponsorer og publikum. Oslo: Unipub.

Berger, A.A. (1992). Popular Culture Genres. Theories and Texts. Newbury Park, London \& New Delhi: Sage.

Berland, J. (1993). 'Radio Space and Industrial Time: The Caso of Music Formats'. In T. Bennett, S. Frith, 
L. Grossberg, J. Shepherd \& G. Turner (Eds.), Rock and Popular Music. Politics, Policies, Institutions. London \& New York: Routledge, s. 104-118.

Bolin, G. (2002). "In the Market for Symbolic Commodities. Swedish Lottery Game Show 'Bingolotto' and the Marketing of Social and Cultural Values". In Nordicom Review vol. 23:1-2, pp. 177-204.

Bolin, G. (2004). 'The Value of Being Public Service. The Shifting of Power Relations in Swedish Television Production'. In Media, Culture \& Society vol. 26:2, pp. 277-287.

Bolin, G. (2005). 'Notes From Inside of the Factory. The Production and Consumption of Signs and Sign Value in Media Industries'. In Social Semiotics vol 15:3, pp. 289-306.

Bolin, G. \& Forsman, M. (2002). Bingolotto: produktion, text, reception (Mediestudier vid Södertörns högskola 2002:1). Huddinge: MKV.

Bourdon, J. (2000). 'Live Television is Still Alive: On Television as an Unfulfilled Promise'. In Media, Culture \& Society, vol. 22, pp. 531-556.

Bruun, H. (1999). Talkshowet. Potret af en tv-genre. København/Valby: Borgen.

Caldwell, J.T. (1995). Televisuality. Style, Crisis, and Authority in American Television. New Brunswick, N.J.: Rutgers University Press.

Cawelti, J.G. (1976). Adventure, Mystery, and Romance: Formula Stories as Art and Popular Culture. Chicago: University of Chicago Press.

Dahl, H. F. \& Høyer, R. (2003). Spillet om TV2. Da Norge fikk kommersielt fjernsyn. Oslo: N.W.Damm \& Søn.

Feuer, J. (1983). 'The Onset of Live Television: Ontology as Ideology'. In E.A. Kaplan (Ed.). Reading Television. Los Angeles: AFI, pp. 12-22.

Fiske, J. (1987). Television Culture. London \& New York: Routledge.

Haettner Aurelius, E. \& Götselius, T. (Eds.) (1997). Genreteori. Lund: Studentlitteratur.

Hall, S. (1971/1996). 'Technics of the Medium'. In J. Cor- ner \& S. Harvey (Eds), Television Times. A Reader. London: Arnold, s. 3-10.

Heat, S. \& Skirrow, G. (1977). 'Television: A World in Action'. In Screen, vol. 18:2, pp. 7-59.

Jantzen, G. \& Møller, V. (1993). 'Tryghed. lighed og broderskab. Om tv-bingo som en elektronisk populærkultur'. In Kultur \& Klasse vol. 20: 2, s. 133-164.

Moran, A. (1998). Copycat Television. Globalisation, Program Formats and Cultural Identity. Luton: University of Luton Press.

Moran, A. (2004): 'Television Formats in the World/The World of Television Formats'. In A. Moran \& M. Keane (Eds.). Television Across Asia. Television Industries, Programme Formats and Globalisation. London \& New York: RoutledgeCurzon, pp. 1-8.

Neale, S. (1980). Genre, London: BFI.

Neale, S. (1990). 'Questions of Genre' In Screen, vol. 31: 1, s. 45-66.

Sjögren, O. (1997). Den goda underhållningen. Nöjesgenrer och artister $i$ Sveriges radio och TV 1945-1995. Stockholm: Stiftelsen Etermedierna i Sverige.

Skovmand, M. (1992). 'Barbarous TV International. Syndicated Wheels of Fortune'. In M. Skovmand \& K.C. Schrøder (Eds.). Media Cultures. Reappraising Transnational Media. London \& New York: Routledge, pp. 84-103.

Todorov, T. (1975). The Fantastic. A Structural Approach to a Literary Genre. Cleveland, Ohio: Western Reserve University Press.

Wilson, T. (1993). Watching Television. Hermeneutics, Reception and Popular Culture. Cambridge: Polity Press.

Zimmermann, P.R. (1995). Reel Families. A Social History of Amateur Film. Bloomington \& Indianapolis: Indiana University Press.

Göran Bolin er professor i Medie- och Kommunikationsvetenskap ved Södertörns högskola i Stockholm 